\title{
On the relationship between antitrust and strategy: taking steps and thinking ahead
}

\author{
Sobre a relação entre o antitruste e a estratégia: onde estamos e para onde podemos ir \\ Sobre la relación entre la defensa de la competencia y la estrategia: dónde estamos y hacia dónde \\ podemos ir
}

\author{
Guilherme Fowler de Avila Monteiro* \\ Insper Instituto de Ensino e Pesquisa, São Paulo, SP, Brazil
}

Received 27 January 2016; accepted 4 July 2016

Available online 13 May 2017

Scientific Editor: Paula Sarita Bigio Schnaider

\begin{abstract}
In this paper, I examine the role that strategic analysis has played on antitrust and discuss new analytical venues. In order to accomplish this goal, the paper presents two directions. Initially, I undertake a review of the current debate between antitrust and strategy. I argue that much of the contemporary discussion on the subject is founded on traditional economic approaches to strategy, what leads to the disregard of the role of firm heterogeneity in competitive dynamics. In the second part of the paper, I sketch an approach to antitrust based on the resource-based view of strategy. This approach is particularly useful in examining the conditions of market rivalry, being a complement - not necessarily a substitute - to the traditional antitrust economic analysis.

(C) 2017 Departamento de Administração, Faculdade de Economia, Administração e Contabilidade da Universidade de São Paulo - FEA/USP. Published by Elsevier Editora Ltda. This is an open access article under the CC BY license (http://creativecommons.org/licenses/by/4.0/).
\end{abstract}

Keywords: Strategy; Antitrust; Market power; RBV

\section{Resumo}

Neste artigo, é examinado o papel que a análise estratégica tem desempenhado no antitruste e são discutidos novos caminhos. A fim de alcançar este objetivo, o trabalho apresenta duas direções. Inicialmente, realiza-se a revisão do debate atual sobre a relação entre antitruste e estratégia. Defende-se que grande parte da discussão contemporânea sobre o assunto se baseia em abordagens econômicas tradicionais de estratégia, o que leva à desconsideração do papel da heterogeneidade da firma na dinâmica competitiva. Na segunda parte do artigo, é esboçada uma abordagem de antitruste fundamentada na visão baseada em recursos. Esta abordagem é particularmente útil para examinar as condições de rivalidade do mercado, sendo um complemento - e não necessariamente um substituto - à análise econômica antitruste tradicional.

(C) 2017 Departamento de Administração, Faculdade de Economia, Administração e Contabilidade da Universidade de São Paulo - FEA/USP. Publicado por Elsevier Editora Ltda. Este é um artigo Open Access sob uma licença CC BY (http://creativecommons.org/licenses/by/4.0/).

Palavras-chave: Estratégia; Antitruste; Poder de mercado; RBV

\footnotetext{
* Correspondence to: Rua Quatá, 300, CEP 04504-2369, São Paulo, SP, Brazil.

E-mail: gfamonteiro@gmail.com

Peer Review under the responsibility of Departamento de Administração, Faculdade de Economia, Administração e Contabilidade da Universidade de São Paulo - FEA/USP.
} 


\section{Resumen}

En este artículo se evalúa el papel que el análisis estratégico ha jugado en la defensa de la competencia y se discuten nuevos caminos. Para ello, se presentan dos direcciones. Inicialmente, se lleva a cabo una revisión del actual debate sobre la relación entre la defensa de la competencia y la estrategia. Se argumenta que gran parte de la discusión contemporánea sobre el tema se basa en los enfoques económicos tradicionales de estrategia, lo que lleva a ignorar el papel de la heterogeneidad de la organización en la dinámica competitiva. En la segunda parte del artículo, se describe un enfoque de antimonopolio que se apoya en la visión basada en recursos. Este enfoque es particularmente útil para examinar las condiciones de competencia del mercado, y puede complementar - y no necesariamente reemplazar - el análisis económico antitrust tradicional.

(C) 2017 Departamento de Administração, Faculdade de Economia, Administração e Contabilidade da Universidade de São Paulo - FEA/USP.

Publicado por Elsevier Editora Ltda. Este es un artículo Open Access bajo la licencia CC BY (http://creativecommons.org/licenses/by/4.0/).

Palabras clave: Estrategia; Defensa de la competencia; Poder de mercado; RBV

\section{Introduction}

The antitrust analysis is widely recognized as an interdisciplinary field of research and practice, within which economics and the law establish a fruitful dialog. As an ultimate expression of this synergy, it is common to find economics professors teaching antitrust courses in law schools, mainly in Europe and the US. Building on this interdisciplinary perspective, I argue in the present paper that in addition to economics and the law, the antitrust analysis can draw inspiration from a third discipline: strategy.

Although the above claim is not fundamentally new (see Foer, 2002, 2003; Hawker, 2003; Oberholzer-Gee \& Yao, 2010), it is proposed here that much of the previous discussion on antitrust and strategy has been narrowly based on the theoretical approach proposed by Porter (2001). The objective of this perspective paper is then twofold: (i) to undertake a review of the debate between antitrust and strategy and (ii) to present a framework inspired by the resource-based view of strategy (Barney, 1991; Peteraf, 1993), which can shed light on new aspects so far disregarded by the traditional antitrust analysis.

In general terms, the importance of this theoretical exercise should not be underestimated. The antitrust policy is an important component of the institutional environment in which firms establish their perpetual struggle to achieve sustained competitive advantages. The economic theory usually applied to antitrust analysis, in turn, is a limited analytical tool since it is more concerned with understanding the structure and functioning of specific markets, casting a macroscopic look at firms' strategies. For that reason, the strategy scholarship has the potential to help the advancement of the antitrust analysis.

The present article is divided into three parts besides this introduction. Section 'Taking steps: what do we know about the relationship between antitrust and strategy?' makes a broad review of the literature on antitrust and strategy, stressing its potentialities and weaknesses. Section 'Thinking ahead: is there a role for strategic analysis within antitrust?' then explores new analytical venues on the subject, specifically presenting a complementary framework for the antitrust analysis of market rivalry. Section 'Conclusion' concludes the discussion, posing questions for future research.
Taking steps: what do we know about the relationship between antitrust and strategy?

The idea of incorporating concepts from strategy - and more generally from management - in the antitrust analysis is not unprecedented. Foer (2002, 2003), for example, usually resorts to the image of antitrust as a three-legged stool, which has been resting precariously on only two of them. These two legs are the Law School and the Department of Economics. The third missing leg is the Business School. The underlying claim is that the antitrust analysis does not take into account the firm itself and the individual decision makers within the firm. More importantly, the Business School would be a counterpoint to what is understood as the analytical limitations imposed by neoclassical economics. As noted by Hawker (2003), in the heart of the Chicago approach to antitrust is the hypothesis (arising from the neoclassical price theory) that firms rationally seek to maximize their profit. The focal point of strategic management, however, is not the maximization of profit per se, but obtaining a sustained competitive advantage.

The concept of sustained competitive advantage is associated with the idea of corporate success in terms of above-normal performance (i.e., economic rents) for an indefinite period of time. According to Barney (1991), a firm has a competitive advantage when establishing a strategy of value creation that is not simultaneously implemented by any competitor. This advantage is, moreover, sustained when actual and potential competitors are unable to duplicate the benefits associated with the strategy. Because the building of sustained competitive advantage is a tentative process, Foer (2003) argues that business schools have the ability to help the antitrust to move beyond the neoclassical abstractions of the economic man - i.e., the perfectly rational individual found in the ideas espoused by the Chicago approach. ${ }^{1}$ In addition, business schools have something important to say about competitive dynamics, which are not fully captured by neoclassical assumptions (e.g., Oberholzer-Gee \& Yao, 2010; Pleatsikas \& Teece, 2001).

\footnotetext{
${ }^{1}$ Leary (2003) notes that "[a]11 I will say here, in summary, is that I believe our present methods of antitrust analysis are still mired too much in an obsolete view of what competition is all about and that they are likely to become increasingly unrealistic".
} 
Despite this potential, Oberholzer-Gee and Yao (2010) find that the influence of strategic thinking in the antitrust field is virtually zero. ${ }^{2}$ According to the authors, while numerous factors probably contribute to this limited influence, three aspects deserve special consideration: In an essential level, antitrust law is primarily focused on the welfare of the consumer. Although economists normally analyze the effects of business conducts on the welfare of consumers and producers, strategists are focused almost completely on the welfare of the producer. A second reason is that strategy scholarship adopts various approaches and is perhaps less accurate in its predictions compared with economics. Given the diversity of approaches used by strategy researchers, in conjunction with the myriad of factors that may influence the success of a firm, it is without surprise that the field of strategy has produced many competing theories about the precise sources of superior performance of the firm. Finally, a third possible reason may be the lack of enthusiasm within antitrust to carry out accurate assessments of different justifications for past and expected business conducts.

Hawker (2003) highlights two additional problems that must be addressed by anyone who seeks to apply business scholarship in antitrust analysis. First, one should select a particular discipline among the multitude of disciplines that comprise the business curriculum. Second, the academic management research does not have a readership among business managers as widespread as academic legal research has between lawyers. Consequently, academic research can provide insights on business thinking, but even mainstream academic journals do not directly influence the thinking of businessmen.

Together, the references discussed above highlight the potential gains and indicate the low penetration of management and strategic thinking on antitrust analysis. The first, and to the best of my knowledge the only attempt to formulate a framework for antitrust analysis explicitly based on strategy dates back to the work of Michael Porter presented at a symposium sponsored by the American Bar Association (ABA) in 2001. ${ }^{3}$ In what follows, I analyze Porter's approach, as well as the criticism made against it.

\section{The Porter's approach to antitrust}

The main objective of the 2001 ABA symposium was to discuss the appropriate role of market concentration on merger reviews from the perspective of antitrust law. ${ }^{4}$ Inspired by this

\footnotetext{
2 In order to analyze the influence of strategic management in antitrust, Oberholzer-Gee and Yao (2010) measure the prevalence of "strategic ideas" in antitrust policies and procedures. To do so, the authors conducted a comparison of numbers of citations. First, they compare the number of times that judicial decisions and legal journals cite renowned researchers in the areas of strategy and microeconomics. Secondly, they tabulate the citations to the three major journals in strategy and its economic counterpart. Finally, they search for references to concepts that are central to the strategy and industrial organization.

3 The American Bar Association's Antitrust Section Task Force on Fundamental Theory, Washington, D.C., January 2001.

4 The Task Force Mission Statement provided that " $[\mathrm{t}] \mathrm{he}$ Task Force on Fundamental Theory will examine whether the concentration thesis underlying the government's present approach to merger control has any continuing validity, in
}

question, Porter (2001) sketched an antitrust approach whose essential point is the growth of productivity.

Porter (2001) takes a critical attitude in relation to the traditional antitrust approach. He argues that although the stated role of the antitrust policy is to promote and protect competition on behalf of consumers' welfare, this rationale is often unclear, understood wrongly or with a very limited scope, focusing too much on market concentration and price settings. In the conception of Porter (2001), the antitrust should be concerned, above all, with the growth of productivity, since this is the most important determinant of both the consumers' long-term welfare and the standard of living of a country.

Porter (2001) notes that productivity growth is associated with innovation, which in turn is manifested through the commercialization of products and services of higher value to the consumer along with the development of more efficient modes of production. The innovative process is greatly dependent on the presence of a strong competition in the marketplace. According to the author, this is the primary justification for the existence of an antitrust policy: to safeguard competition as an inducer of innovations that raise the productivity of the economy. The main goal of the antitrust policy is then to encourage a dynamic process of improvement (i.e., innovations in product, process, and management), given its effect on productivity growth. ${ }^{5}$ In such a case, higher prices should be an antitrust warning sign only if it is not associated with an increasing value delivered to the consumer. ${ }^{6}$ In this same light, the high profitability of a firm is not an issue of concern when it reflects superior products or benefits obtained by means of operational efficiency (see also Demsetz, 1973).

Regarding the implementation of antitrust policy, Porter (2001) notes that standard antitrust procedure - i.e., the examination of the number of firms in a market, its concentration and profitability - captures only a small part of a more complex phenomenon, at the same time that it deflects analysis to less productive debates about where to place the boundaries of the relevant market. As an alternative, Porter (2001) proposes the use of the five forces analysis framework (Porter, 1985). Any of the five forces (internal rivalry, entry, substitute products and services, customers and suppliers) can be significant in determining competition, depending on the specific industry under

view of the empirical and theoretical work of the past several decades, most of which suggests that concentration as such is a poor predictor of actual conduct adverse to the competitive process".

5 As noted by Davidson (2012), these ideas expressed by Porter are not entirely inconsistent with the traditional antitrust thinking.

"[...] monopoly profits are an unwarranted transfer of income from consumers to producers, but a much more significant economic effect of competition is the encouragement of innovation. That innovation is the source of maintaining and increasing the standard of living in the United States and throughout the world".

\footnotetext{
${ }^{6}$ It is interesting to note the existence of a latent contradiction between the idea of higher prices reflecting higher value delivered to the customer and the notion expressed in the Horizontal Merger Guidelines (U.S. Department of Justice and Federal Trade Commission) that market power refers to "the ability to profitably maintain prices above competitive levels for a significant period of time".
} 
examination. Equally important, for any of the five forces, the causes of competitive intensity are multidimensional, i.e., it goes beyond the price.

The multidimensional nature of rivalry among firms is important in order to understand the link between competition and productivity. According to Porter (2001), some forms of rivalry have a greater impact on productivity, being more valuable to society. For example, if cost/price margins are used as a metric of social benefit, then the strategy of imitation and price discounting seems ideal from the traditional antitrust point of view; however, from the viewpoint of productivity growth, this type of competition could lead to a less intense dynamic improvement of the economy. By contrast, competition based on differentiation can generate a larger set of choices for consumers as well as more intense innovation in products and processes. In other words, when considering productivity growth as a standard for antitrust, one should be aware of the kind of competition that is pursued within a country. This brings us to a second analytical step: examining the nature of local competition.

Porter (1990) notes that even in locations where firms compete internationally, the vitality of local competition is crucial to the increasing of productivity. The local competition has the power to create positive externalities for the firm - for example, through the stimulus for market rivalry and innovation, as well as the increased availability of skilled labor, information and resources. Accordingly, when the local rivalry is cooled down, a country suffers two effects: not only firms in the industry have less incentive to be productive, but also the entire business environment becomes less productive. According to Porter (2001), the appropriate tool to examine local competition is the diamond model (Porter, 1990) in which six factors interact to create favorable conditions for innovation. ${ }^{7}$

From an antitrust perspective, both the five forces analysis and the diamond model are analytical tools used in order to answer a central question: how a merger (if approved) would affect productivity growth? Although Porter (2001) recognizes that the direct estimation of productivity growth is a difficult task, the relationship between competition and the long-term increase in productivity enables the development of an analytical framework divided into three stages. First, the antitrust analyst should examine the significance of the merger (or joint venture), as well as the basic conditions for productivity growth. This involves three steps. (i) Identification of the set of relevant markets and submarkets associated with the merger, and the geographical area in which one can find local externalities. (ii) Definition of a market share threshold above which mergers will be analyzed more carefully. ${ }^{8}$ (iii) Identification of the historical performance of the industry and firms, as well as the characterization of the robustness of rivalry in the industry.

\footnotetext{
7 The six factors that encompass the model are: (i) factor conditions (human resources, physical resources, knowledge resources, capital resources and infrastructure), (ii) demand conditions, (iii) related and supporting industries, (iv) firm strategy, structure and rivalry, (v) government, (vi) chance events (i.e., events outside the control of a firm).

8 Porter suggests a $50 \%$ threshold.
}

In the second stage, the analyst must undertake a complete competitive assessment, using five forces analysis and the diamond model. The goal is to predict the effects of the merger on productivity growth. Specifically, the five forces analysis is used to measure the competition in the industry taking into account all markets and submarkets identified in the previous stage. Since a number of factors affects each force, the analyst must scrutinize each particular factor. The starting point is to identify the base level of each factor and the direction it is moving before and after the merger (increasing, decreasing, or steady).

Finally, in the third stage, if it is found that there are significant adverse effects on the competition in the industry or on the local competition, one should examine the direct effect of the merger on productivity growth. The key questions are: Does the operation generate significant and verifiable benefits to facilitate productivity growth? Are such benefits perpetual or limited to a specific instant of time? What is the probability that the gains are actually realized? In answering these questions, the antitrust analyst can make a decision on the merger.

Porter (2001) lists the advantages of using the five forces analysis for the examination of mergers and acquisitions. According to the author, the traditional antitrust analysis is built upon a short-term, static look, other considerations being aggregated in the analysis as "adjustment arguments". The strategic analysis, in turn, is based on a multidimensional concept of competition and is not focused solely on price. Strategic analysis also makes the precise definition of the boundaries of the relevant market dispensable, since it embodies all the major influences on competition. ${ }^{9}$ Accordingly, the indexes of market concentration (e.g., Herfindahl Hirschman Index - HHI) lose their prominent position in the antitrust analysis. This perspective on antitrust found a strong supporter in Weller (2001a, 2001b). In advocating the application of the approach in the antitrust analysis, Weller (2001b: 47) notes that:

"The Productivity Paradigm is fundamentally new and different in numerous ways. Productivity replaces efficiency, and standard of living replaces consumer welfare, as primary goals; it does not use concentration theory, HHIs, profitability, price increases and other tools of current antitrust analysis to determine the legal issue of whether or not a substantial lessening of competition is likely; it eliminates the need to determine the relevant market; it uses new empirical tools that are measurable, understandable and rigorous like the widelyused Five Forces analysis, Diamond analysis of the business environment, and the Market Share Instability Index [...]".

\section{Criticism}

When called upon to assess Porter's proposal, Einhorn (2001), Baker and Salop (2001), and Werden (2001) formu-

\footnotetext{
${ }^{9}$ For the delimitation of a relevant market, the traditional antitrust analysis assesses the behavior of a hypothetical monopolist, taking account of its capacity to make a "small but significant no transitory increase in price" (SSNIP test) of all products in a certain market. The relevant market is defined as the smallest grouping where such a price increase can be sustained in a profitable manner.
} 
lated strong counterarguments to the application of the five forces analysis and the diamond model in the traditional antitrust analysis. According to Einhorn (2001) Porter (2001) does not consider the fact that measures of concentration as indicated in the Horizontal Merger Guidelines represent only a first-round screening process. It not only allows for the identification of "safe harbors", but also provides a first approach to the problem, so that larger operations that raise competition concerns may be investigated in more detail. Moreover, Baker and Salop (2001) note that modern economic theory does not support the idea that market concentration is useless as a guide for merger analysis.

Einhorn (2001) also argues that, contrary to that suggested by Porter (2001), price-based competition is generally more important than productivity aspects in a significant number of industries. In addition, although the development of new products is an extremely important aspect of economic development, this is not something that can be easily foreshadowed by the courts or by experts without a considerable degree of subjectivity. Accordingly, it is proposed that Porter (2001) fails to define the conditions necessary for a comprehensive analysis of productivity, with appropriate empirical measures and a theoretical model that relates the five forces to identifiable parameters in a given merger.

A third object of criticism is the fact that the productivitybased approach disqualifies the definition of the relevant market as a fundamental aspect of antitrust analysis. Werden (2001: 68) makes the following comment with reference to Weller (2001b):

"Mr. Weller apparently would include [in a relevant market] distant substitutes, complements to them, products produced with similar inputs, inputs into the production of the products in question, and products produced using the products in question as inputs. Casting the net this broadly may be useful in identifying all of the factors that may somehow affect prices or outputs, but it does not identify the locus of likely anticompetitive effects".

Finally, the authors criticize the suggestion - incorporated into the second stage of Porter's analysis - to define the direction in which each factor that influences the five forces is moving before and after the merger (increasing, decreasing, or steady). Werden (2001: 69), for instance, argues that

"[T]here is no mechanism (for example, no use of economic models) for determining whether a change in intensity classification is likely to materially affect price, output, quality, or any other index of industry performance, nor one for trading off opposing changes in intensity classifications".

On a more elementary level, the various commentators consider that Porter's contribution to the antitrust analysis is per se limited to the extent that both the antitrust and the five forces analysis seek inspiration from the same theoretical framework, namely the Industrial Organization. Porter was successful in reversing the logic of the structure-conduct-performance paradigm, ${ }^{10}$ providing tools for managers to understand the competitive landscape of an industry and thereby to develop strategies in order to lessen the competitive pressures. Under this view, it is argued that Porter's contributions to antitrust may be only marginal (i.e., amendments to the current Guidelines). ${ }^{11}$ At the end of the day, as already evidenced by Oberholzer-Gee and Yao (2010), the Porter's approach failed to become a reference in antitrust and therefore the antitrust three-legged stool has not yet found its missing leg. In what follows, I present some new ideas that may clear the way in the search for a contribution from strategy for antitrust analysis. As will be seen, the path taken differs from that originally proposed by Porter (2001).

\section{Thinking ahead: is there a role for strategic analysis within antitrust?}

Although the strategic approaches inspired by Industrial Organization (notably, the five forces analysis) are widespread in the corporate world, the strategic scholarship witnessed the emergence of a new strategic approach in the 1980s, the so-called Resource-based View (RBV) (e.g., Barney, 1991; Peteraf, 1993; Rumelt, 1984; Wernerfelt, 1984). According to Foss (2005), it was only after the advent of the RBV that strategy found its current configuration: the key aspect of strategic management involves creating and sustaining a competitive advantage at the firm level, where a sustained competitive advantage is interpreted in terms of extraordinary rents obtained in equilibrium.

In contrast to the five forces analysis, the RBV casts a more microscopic look at the business agents, having as a unit of analysis the firm's resources. From the perspective of the RBV, firms control a set of productive resources which vary from company to company. A resource can be valuable in a particular industry or a particular moment in time, and may not have the same value in another industry or in a different context. More importantly, the resource heterogeneity among firms explains the achievement of competitive advantage. The concept of heterogeneity is central because it helps explain the existence of differences in economic performance between firms that operate within the same industry. This aspect is largely neglected by strategic analysis inspired by Industrial Organization.

Accordingly, Barney (1991) and Peteraf (1993) take on two assumptions when developing their strategic approaches founded on a resource-based view. The assumptions are: (i) firms within an industry are heterogeneous with respect to the strategic

\footnotetext{
10 The Structure-Conduct-Performance model was developed in the 1930/40 at Harvard University, becoming one of the initial references of Industrial Organization. The model is concerned with causal flows that build on the basic conditions and market structure toward the behavior and performance of firms. The objective is to describe the conditions for increasing competitiveness of industries, having served as a major inspiration for antitrust policy in its early days. See generally Scherer and Ross (1990).

11 Yet, it is remarkable that Porter's appeal toward a more holistic understanding of the competition - i.e., taking into account extra-price factors - has been discarded with reckless speed, especially in the corridors of the antitrust agencies.
} 
resources they control and (ii) the resources do not have perfect mobility, which contributes to the perpetuation of heterogeneity for a reasonable period of time. Considering the existence of imperfect mobility of resources, the creation and sustainability of economic rents becomes possible. Barney (1991) and Peteraf (1993), however, develop different approaches to the RBV (see Foss, 2005). Barney (1991) is primarily focused on the building of sustained competitive advantages derived from Ricardian rents. ${ }^{12}$ Peteraf (1993), on the other hand, explicitly considers the building of sustained competitive advantage from both Ricardian rents and monopoly rents. ${ }^{13}$ For the purposes of this article, the approach advanced by Peteraf (1993) is more convenient since the author explicitly considers the possibility of the firm obtaining monopoly rents, the object of antitrust analysis.

Peteraf (1993) argues that resources controlled by the firm generate a sustained competitive advantage when four cornerstones are present: (i) resources are heterogeneous within the industry, so that the firm can generate superior incomes (Ricardian or monopoly rents); (ii) the existence of ex post limits on competition, so that the rent is not dissipated by competition in the product market; (iii) resource mobility is imperfect, allowing the preservation of the economic rent within the firm; (iv) existence of ex ante limits on competition, indicating that the market of productive factors is unable to appropriate all income generated by the resources.

In what follows, I discuss how these ideas can be incorporated into the antitrust analysis.

\section{Toward a resource-based dialog within antitrust}

The strategic analysis inspired by the resource-based view can be of particular help in the antitrust analysis of the competition pattern in an industry. Specifically, the RBV can shed light on competitive peculiarities that would remain hidden in a more traditional economic assessment. In order to make my argument more precise, I roughly divide the antitrust analysis of mergers and acquisitions in four sequential steps:

(i) The analysis begins with the definition of the relevant market of the merger.

(ii) Based on this definition, the analyst proceeds in the calculation of market shares of the firms before and after the merger. The goal is to identify whether the firm resulting

\footnotetext{
${ }^{12}$ Ricardian rents arise because of the presence of superior productive factors, which are limited in supply.

${ }^{13}$ Peteraf (1993: 182) notes that "[i]n monopoly models, heterogeneity may result from spatial competition or product differentiation. It may reflect uniqueness and localized monopoly. It may be due to the presence of intra-industry mobility barriers which differentiate groups of firms from one another (Caves and Porter, 1977). It may entail size advantages and irreversible commitments or other first mover advantages. There are numerous such models. What they all have in common is the supposition that firms in favorable positions face downward sloping demand curves. These firms then maximize profits by consciously restricting their output relative to competitive levels. These are models of market power. Unlike Ricardian models, many are 'strategic' in that firms take into account the behavior and relative position of their rivals".
}

from the merger holds a market share sufficiently high as to make credible any possible abuse of market power.

(iii) Assuming that the firm resulting from the merger presents a high market share, the analyst is supposed to examine the pattern of competition in the industry. The goal is to determine whether the remaining agents in the market are able to compete effectively with the firm resulting from the merger.

(iv) Based on the hypothesis that the pattern of competition in the industry is not enough to mitigate the abuse of market power, one must examine the efficiencies associated with the operation. The goal of this step is to compare the gains arising from the merger with the potential damage to competition indicated in the previous steps.

In its usual template, the analysis of the pattern of industry competition (step iii) essentially involves four aspects: the role of imports (are imports an effective remedy against the exercise of market power?), the conditions of entry of new competitors in the industry, the way rivalry is expressed in the market, and the existence of conditions for the coordination of decisions in the industry. Specifically regarding the analysis of market rivalry, it is expected that competitors be able to absorb a significant share of the market in response to the exercise of market power by the merged firm. The rivalry is considered not effective when competitors operate at full capacity, the expansion of the production capacity of the rival firms is not economically feasible in less than two years, the expansion of production involves high costs or, in the case of differentiated products, consumers are characterized by high brand loyalty.

This way of understanding market rivalry clearly indicates the influence of Industrial Organization on the antitrust analysis. When addressing a particular case, an antitrust analyst tries to characterize the rivalry in the relevant market. To this end, he or she assumes that firms are roughly equivalent (except for the presence of differentiated products) and examines the industry as a whole. Recent (or not-so-recent) models of demand systems with which merger simulation can be performed explicitly recognize differences among firms' products and predict the likely conduct following a merger (see, for instance, Carlton \& Keating, 2015; Coate \& Ulrick, 2016; Nevo, 2000). This type of approach has positive aspects, allowing, for example, the identification of the competitive pattern of the market (Bertrand competition, Cournot competition, etc.). Yet, considerations of individual firms and their resources are, in most cases, ignored. Even when the analyst seeks to incorporate in her analysis more subtle aspects of the firms, she finds herself at a loss since she does not have suitable analytical tools. As a result, more detailed analyses of the firms are at risk of becoming mere anecdotal reports.

It is exactly at this point that the analysis inspired by the resource-based view can contribute to antitrust analysis. In order to better understand the rivalry between firms in a market, the analyst may ask herself: Have companies in this industry sustained competitive advantages? Resorting to the logic proposed by Peteraf (1993), this issue unfolds in four questions. 
Does the firm have economic rent? What is the nature of this rent?

If a firm has a sustained competitive advantage, this means that it produces some level of economic rent. As previously noted, firms may have Ricardian rents or monopoly rents. On the one hand, the condition of heterogeneity between firms may be associated with the presence of superior production factors, which are limited in supply. These factors of production are the basis of Ricardian rents: the firms that own the production factors are able to get higher profits precisely because there is a shortage in the supply of underlying valuable resources. On the other hand, the heterogeneity of firms may result from spatial competition (Hotelling competition), product differentiation, barriers to mobility within the industry itself, advantages derived from size (e.g., economies of scale), etc. These resources are the basis of monopoly rents because they allow the firm to deliberately restrict its production without all customers stopping consumption of the good or service.

It is interesting to note that according to the structureconduct-performance paradigm, if a firm gains persistently above normal profits, it is assumed that some form of market power exists in the market. Quite the reverse, the Chicago School assumes that in the absence of barriers to trade supported by the state, the higher profitability of the firm indicates higher production arrangements. The RBV is in the middle ground: although not denying the possibility of monopoly profits, the RBV also considers the possibility that above normal returns represent Ricardian rents associated with particular resources held by the firm (Locketta \& Thompson, 2001). The antitrust analyst must therefore understand the origin of the superior performance of the firm.

\section{Does the economic rent offset the cost incurred?}

Assuming a firm has monopoly profit, a key condition must be met in order for the firm to sustain this competitive advantage. As a matter of logic, before any firm establishes a superior position, there must be limited competition for that position; otherwise the market competition would erode any differential income. In other words, there must be ex ante limits to competition.

The condition of ex ante limit to competition is analyzed within the RBV as a condition of imperfection in the factor market in such a way that competition between economic agents does not generate an excessive rise of the cost (price) of strategic resources. Given the existence of market imperfections, a firm is able to acquire a resource at a lower price than the present value of the income stream associated with the resource itself. This condition ensures that the firm will be able to effectively generate a positive flow of income. In contrast, in the absence of market imperfections, firms could obtain only normal profits.

\section{Is the economic rent challenged?}

The mere fact that a company earns an economic rent (i.e., achieves a competitive advantage) does not indicate that the firm is successful in sustaining this rent. The sustainability of the competitive advantage requires that the condition of resource heterogeneity be preserved. If heterogeneity is a phenomenon of short duration, the income is short-lived and the firm enjoys temporary competitive advantage. Thus, subsequent to the firm establishing a superior position - and thereby earning rents - there must be forces that limit competition for those rents (Peteraf, 1993). In other words, the rent is only sustained when there are ex post limits to competition. The concept of an ex post limit to competition is not restricted to the idea of barriers to entry. As noted by Locketta and Thompson (2001: 746): “firms that have superior resources and/or are better at deploying those resources than others will be able to earn above average returns. However, in the presence of changes in demand and innovation, sustained above average returns do not necessarily indicate the presence of barriers to entry".

According to Peteraf (1993), the RBV emphasizes two critical factors that determine the sustainability of income, namely: imperfect substitutability and imperfect imitability. In general, the presence of substitutes reduces the income of a firm by making the demand curve of a monopolist or oligopolist more elastic. On the other hand, firms can take advantage of isolating mechanisms in order to gain protection against imitation and thereby preserve their income. According to Rumelt (1984), isolating mechanisms include property rights to scarce resources, information asymmetry, switching costs and buyer's search costs, reputation, and economies of scale associated with specialized assets.

Barney (1997) argues that the cost disadvantage of a specific competitor to imitate a resource may be derived from three sources, beyond the legal protection provided by patents. First, the acquisition or development of a resource can be based on specific historical conditions. In this case, the firm that owns the resource is characterized by first mover advantage or path dependence. Secondly, the imitation of a resource can be costly due to the presence of causal ambiguity between the resource and the competitive advantage - that is, managers may not fully understand the relationship between resource and economic profit. This type of situation occurs generally when the resources that generate competitive advantage are part of the daily experience of a company and therefore are not noticed. Examples are the organizational culture of the firm and the good relationship with its suppliers. In the third and last place, the imitation of a resource held by the firm can be costly when the resource represents a socially complex phenomenon. In this case, even though one may specify the way in which resources generate competitive advantage (absence of causal ambiguity), the effective imitation of the resource may be too costly. As an example, even assuming that we can clearly identify the organizational culture as a source of competitive advantage in a particular firm, this does not imply that a rival is able to mimic such a culture.

Taken together, the elements listed by Barney (1997) bring an implicit criticism to the theory of contestable markets (Baumol, Panzar, \& Willig, 1982). According to this antitrust theory, a monopolist would be unable to charge monopoly prices under the assumption that entrants can quickly and inexpensively start operations in the market. That is, entrants would incur zero sunk costs, suggesting some sort of symmetry between incumbents and potential entrants. The RBV, in contrast, emphasizes the heterogeneity of firms arising from their particular experience. In a world of path dependent heterogeneity, the sunk cost incurred by 
entrants tends to be ubiquitous (Locketta \& Thompson, 2001). Although this argument does not completely challenge the theory of contestable markets, it suggests that the antitrust analysis must be implemented with care, taking into account the role played by the heterogeneity of the resources held by the firms.

\section{Is the economic rent appropriated by the firm?}

A higher income not being challenged does not mean that it is automatically appropriated by the firm. Economic profit will only be sustained if the resources are characterized by imperfect mobility which ensures that income is tied to the firm.

From the strategic point of view, resource immobility ensures that resource holders are unable to appropriate all of the rents generated within the firm. If resources were mobile, rival firms would be able to get control of the sources of competitive advantage. At the margin, the competition between firms would cause the resource holder to capture the full economic profit. Peteraf (1993) argues that resources are imperfectly mobile when they are somewhat specialized to the specific needs of the firm (Williamson, 1975) or when they are co-specialized (Teece, 1986). Other resources can be imperfectly mobile simply because the transaction costs associated with its transfer are too high.

From the antitrust perspective, the important point to note is that imperfectly mobile resources remain linked to the firm and therefore available for use in the long term. Returning to the discussion on the theory of contestable markets: if the dominant position of a firm in the industry stems from a resource developed over time (path dependence) and, moreover, such a resource cannot be easily removed from the firm (resource immobility), the barriers to entry in the industry are much higher than the traditional antitrust examination may suggest.

In general terms, the RBV teaches us that sustained competitive advantage requires the heterogeneity of the firm, the ex ante and ex post limit to competition, and imperfect mobility of resources. As soon as these conditions are met, the economic profit will be sustained. In antitrust terms, the implications are clear: if a firm is able to generate monopoly profits and simultaneously is able to sustain this profit, then antitrust intervention becomes necessary. A much more subtle issue emerges when one takes into account that not all firms wishing to obtain monopoly profit will be successful. The RBV tells us that monopoly profit is sustained only when the conditions listed above are met. In these terms, it is possible to say that (see also Fig. 1):

- If the cost incurred to establish a competitive advantage is higher than the income earned, economic rationality implies that the firm does not pursue the strategy and thus there is no antitrust concern. The same goes for the case where income is challenged by ex post competition and, simultaneously, the firm finds it difficult to appropriate the income generated.

- When the firm is able to appropriate the income (imperfect mobility of resources), but the income is challenged by ex post competition, the competitive advantage is temporary and may be understood as an inherent part of capitalist dynamics.

- Finally, when resources are mobile and income is not challenged by ex post competition, two situations can happen: (i) the firm may not have the incentive to continue the strategy, since it fails to appropriate the income; (ii) the firm may be in a stable equilibrium so that there is a continuous transfer of income to resource holders. In this case, antitrust intervention is justified, but must be selective - it may be not enough to intervene just in the product market.

\section{Illustration}

I present in this section some empirical evidence. The discussion outlined here should be seen as an illustration and not as a deliberate test of the application of the RBV logic to antitrust. Specifically, I reassess a case analyzed in 2008 by the Office of Fair Trade (OFT), the British antitrust authority. It refers to the acquisition of the online DVD rental business of Amazon (UK) by the company Lovefilm.

As expected, the OFT tried to define the relevant market of the operation in its initial review of the case. To this end, the antitrust authority conducted a critical loss analysis (Harris and Simons, 1991; Katz \& Shapiro, 2003), finding evidence that the relevant market is broader than just the service of online DVD rentals. The OFT, however, faced difficulties in accurately defining a boundary for the market. On the one hand, consumers can access video content in various alternative ways. On the other hand, the OFT failed to unambiguously identify a second best option for content delivery channels for consumers to replace online DVD rental. The OFT chose, then, to analyze the competitive closeness between Lovefilm and Amazon, and between the merged companies and alternative delivery channels.

The OFT drew heavily on field research to measure the diversion ratio of consumers (i.e., the cross-elasticity between goods), and on internal documents of the parties to describe their business practices. The quantitative analysis based on the field study identified the hypothesis that the merger could cause a substantial reduction of competition, giving space for the potential abuse of dominant position by the merged companies. By analyzing the documents submitted by the parties, however, the OFT eventually refuted the hypothesis of negative effects of the merger, once it became clear that the parties consistently monitor and respond to movements of other competitors, including companies that do not operate directly in the market of online DVD rentals.

Of particular interest is the fact that the OFT was unable to clearly identify a boundary for the relevant market. The OFT argued that there is a large number of channels through which consumers can access video content, making it impossible to draw a clear boundary between them. My basic argument is that a resource-based assessment of the case can bring new insights to this analysis. I start from the OFT own description of the channels by which consumers can access film and TV video content. The main characteristics of these alternative channels are presented in Table 1 .

In order to assess the case, I resort to a representation of the competition space as proposed by Peteraf and Bergen (2003) - see Fig. 2. Peteraf and Bergen (2003) introduce two constructs - market needs correspondence and capability 
Table 1

Channels by which consumers can access film and TV video content.

\begin{tabular}{|c|c|c|c|}
\hline Channel & OFT assessment $\mathrm{a}^{\mathrm{a}}$ & Consumption characteristics & $\begin{array}{l}\text { Companies' resource } \\
\text { differentials }\end{array}$ \\
\hline $\begin{array}{l}\text { Online DVD rental } \\
\text { (ODR })\end{array}$ & $\begin{array}{l}\text { Subscription services whereby customers pay a fixed } \\
\text { monthly fee which entitles them to receive through the } \\
\text { post DVDs which they have selected online in advance } \\
\text { from a wide range of titles. Once the customer has } \\
\text { watched a DVD, he/she posts the DVD back to the ODR } \\
\text { supplier in a prepaid envelope whereupon the ODR } \\
\text { supplier sends the next available DVD on the customer's }\end{array}$ & $\begin{array}{l}\text { Home consumption } \\
\text { Home delivery of the movie } \\
\text { Absence of time limit to } \\
\text { return the DVD } \\
\text { Flexibility to watch the movie } \\
\text { according to consumer's own } \\
\text { availability }\end{array}$ & $\begin{array}{l}\text { Movies back catalog } \\
\text { Logistic capabilities } \\
\text { Technology capabilities } \\
\text { (online user interface) } \\
\text { Competence on customer } \\
\text { acquisition and retention } \\
\text { (brand) }\end{array}$ \\
\hline
\end{tabular}

Brick and mortar rental (traditional DVD rental channel)

DVD retail

Pay per view (PPV)

Specialist film channels

Video on demand (VOD)

Internet download
Free to air TV Given free to air TV does not require subscription or

list. Customers have no time limits imposed within

which they must return the DVD and, accordingly, no

late fees are incurred.

Customers pay a set fee per disk to rent a DVD for a night and/or a slightly higher fee for renting for a longer period. Individual brick and mortar stores traditionally do not offer a back catalog (i.e., DVDs that are not recent releases) on the scale of ODR providers. Consumers can purchase DVDs from a number of alternative retail channels. Despite recent price reductions in DVD retail, permanent purchases are still substantially more expensive on a per-unit basis than ODR and other rentals but have the benefit of permanent access to the content.

Dedicated television channels show films at scheduled intervals that consumers can pay for in addition to the television subscription packages of which PPV channels are a part. With PPV the film is shown at the same time to everyone ordering it. Traditionally the number of films available at any given time is small compared to ODR, and access is on a one-off basis but has the advantage of convenience inasmuch as consumers do not need actively to search and select titles in the way required by ODR or brick and mortar rental.

Consumers can subscribe to basic and premium channel packages from cable operators, satellite providers, and telephone companies using cable or IPTV, and other multi-channel distributors through monthly subscription packages. Choice is relatively limited and titles are usually available to consumers later than they are available to buy or rent but, like PPV, specialist film channels have convenience advantages.

VOD operates through a computer server and enables viewers to access content at any time from a pre-determined list of films and TV programs. Unlike PPV, VOD allows consumers to watch a film/TV program at an individual time of their choosing. Choice of back catalog with VOD may be significantly restricted by comparison to ODR but titles can be purchased on a one-off basis rather than by subscription only. incremental payment above the cost of the Freeview box, there is no incremental cost for viewing the content but choice is relatively limited and titles are usually available to consumers later than they are available to buy or rent.

Consumers can gain access to films on their computers via the internet. Once rented, customers typically have $24 \mathrm{~h}$ to view the programs/films.
Home consumption

Flexibility to watch the movie according to consumer's own availability

Home consumption Home delivery of the movie (online purchase)

No return and full use flexibility

Home consumption Home delivery of the movie Reduction in searching and selecting costs

Home consumption Home delivery of the movie Reduction in searching and selecting costs

Home consumption Flexibility to watch the movie according to consumer's own availability

Home consumption Low cost

Home consumption Home delivery of the movie Use flexibility
Shop location

Competence on customer acquisition and retention (brand)

Movie back catalog Logistic and technology capabilities (online purchase)

Technology capabilities (online user interface) Distribution cost is minimal (using an existing channel).

Distribution cost is minimal (using an existing channel).

Technology capabilities (online user interface)

Distribution cost is minimal (using an existing channel).

Technology capabilities (online user interface)

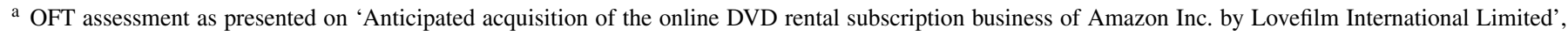
ME/3534/08, at pages 2-5.
} 


\begin{tabular}{cccl}
\hline $\begin{array}{c}\text { Does the economic } \\
\text { rent offset the cost } \\
\text { incurred? } \\
\begin{array}{c}\text { Ex-ante limit to } \\
\text { competition?) }\end{array}\end{array}$ & $\begin{array}{c}\text { Is the economic } \\
\text { rent challenged? } \\
\text { (Ex-post limit to } \\
\text { competition ?) }\end{array}$ & $\begin{array}{c}\text { Is the economic rent } \\
\text { appropriated by the } \\
\text { firm? } \\
\text { (Imperfect mobility?) }\end{array}$ & Antitrust implication \\
\hline No & - & - & $\begin{array}{l}\text { Rent is not sustainable. Lack of antitrust } \\
\text { concern. }\end{array}$ \\
\hline Yes & Yes & Nos & Temporary rent. Lack of antitrust concern. \\
\hline Yes & No & No & $\begin{array}{l}\text { Firm has no incentive to continue the } \\
\text { strategy. } \\
\text { If the firm is in a stable equilibrium, there } \\
\text { is continuous transfer of income to } \\
\text { resource holders. Antitrust intervention is } \\
\text { justified, but must be selective. }\end{array}$ \\
\hline Yes & No & Yes & $\begin{array}{l}\text { Sustainable rent. Antitrust intervention is } \\
\text { needed. }\end{array}$ \\
\hline
\end{tabular}

Fig. 1. RBV analysis in the presence of market power.

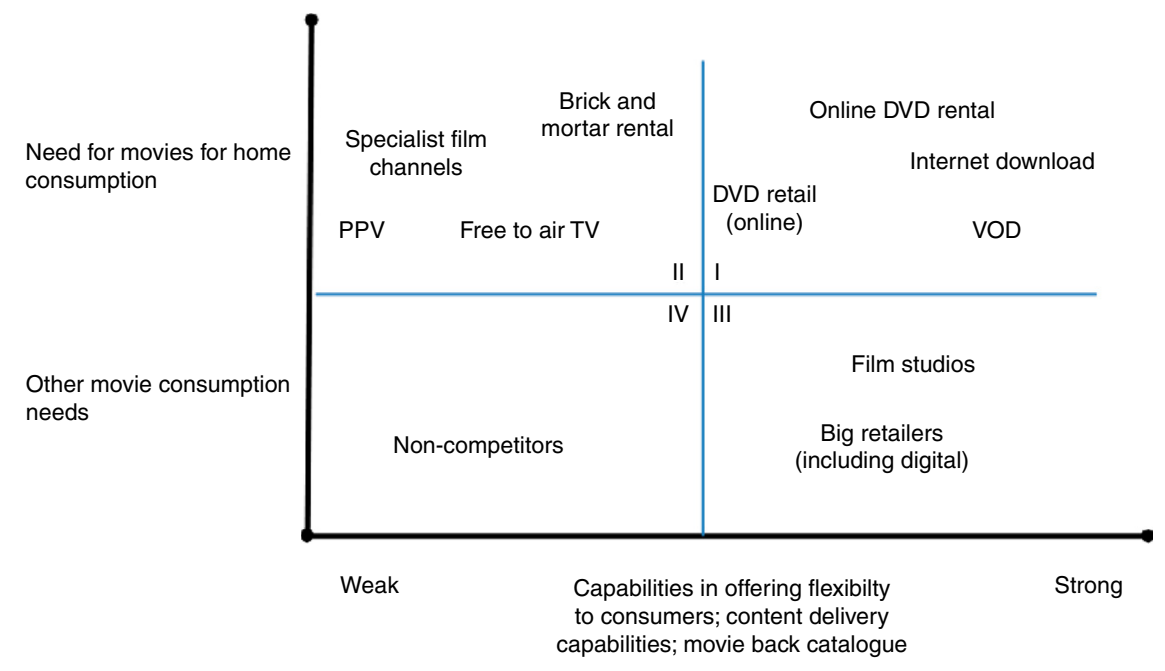

Fig. 2. Characterization of competition - online DVD rental.

Source: Developed by the author based on Peteraf \& Bergen (2003).

equivalence - whose basic function is to allow the assessment of commonalities between companies. Market needs correspondence is a dichotomous indicator that seeks to capture whether a particular company or channel serves or not the same consumer needs as the focal company/channel. Capability equivalence refers to the extent to which a particular company has resource and capability bundles comparable to the resource and capability bundle of the focal company/channel in terms of its ability to meet similar consumer needs. The emphasis is on the role played by resources, which may be dissimilar in kind but similar in use or functionality.

The connection of the two concepts occurs through a graphical representation (see Fig. 2). The $Y$-axis represents the market needs correspondence (measured as yes or no), and the $X$-axis represents the capability equivalence (measured as high or low). Companies in quadrant I are those that meet the consumer need at comparable levels of satisfaction. According to Peteraf and
Bergen (2003), the closest direct competitors of the focal company/channel are included in this set, as well as rival companies offering substitute commodities. Companies located in Quadrant II are those that meet the same basic consumer needs compared to the focal company/channel, but use resources that are not equally well suited for the task. Peteraf and Bergen (2003) indicate that these companies are essentially those which provide vertically differentiated products (i.e., with a different quality level in relation to the focal company). Companies located in Quadrant III are potential competitors of the focal company/channel. These companies, though not meeting a consumer need equivalent to the focal company/channel, have a set of resources and capabilities that allow it to serve the same market with little incremental investment. Lastly, companies in quadrant IV represent, in the view of Peteraf and Bergen (2003), those who are less likely to present competitive threats to the focal company/channel. These companies do not meet a consumer need that matches the focal 
company market, nor have the resources and capabilities that allow them to do so at this point.

Based on Table 1, I define that online DVD rental caters to the consumer need of home movies. More specifically, the online DVD rental enables consumers to watch movies without the need to leave home in order to get the content and offers the flexibility of watching according to their personal availability, over an undetermined period of time. Aiming to offer services that can satisfy this consumer need, companies must possess strong resources and capabilities on film catalog, logistical capabilities (to send movies via mail, control DVD returns and ship new DVDs), technology capabilities (especially regarding the online interface with the consumer) and must also possess a strong brand that encourages retention of consumers.

It is worth noting that the requirements listed above do not represent a set of resources that must necessarily be retained so that a company can compete with the online DVD rental service. In the case of downloading movies via the Internet, for example, it is plausible to assume that this type of channel represents a significant rival of online DVD rental, even if it does not make sense for the company to have a strong competence in logistics. In this particular case, the company must have the technological expertise to enable it to deliver content (i.e., the film) to the consumer as soon as a purchase is made. For the purposes of I analysis therefore, it may be appropriate to consider that companies must possess strong delivery capability, given the business model selected.

One factor that distinguishes channels is consumer flexibility in watching the movie according to their own availability. The flexibility comes from the business model of each type of channel, and is directly associated with the resources that support each business model. As stated, in the online DVD rental model, the consumer can keep the DVD for an undefined period of time (see Table 1). The brick and mortar store, on the other hand, cannot allow the consumer to keep the DVD for an indefinite period. If it does so, consumers would be unable to find the DVD they wanted in the store, and this would erode the attractiveness of the store to consumers. Alternatively, the store could hold a large stock of copies of each video, but that would incur higher stock costs in each store. As another example, it is reasonable to assume that there are technical and commercial aspects justifying the practice of pay per view channels showing a movie on a fixed schedule, leaving the consumer to plan to watch the movie at the specified time. The same reasoning above applies in the case of the delivery convenience (greater when the consumer receives the movie/content at home) and in the case of available movie options (movie back catalog). Once again, both the delivery model and the menu of available movies are associated with the resources that support each business model.

Fig. 2 attempts to illustrate these characteristics. One point to bear in mind is the fact that the resources and capabilities analyzed in the horizontal axis do not represent an exhaustive listing. In fact, there would be little gain in doing so. For the manager/strategist as well as for the antitrust analyst, the point of greatest relevance here is to emphasize the resources that distinguish companies of quadrant I from companies located in quadrant II. ${ }^{14}$ An antitrust analyst could allocate in quadrant I, besides the online DVD rental, the downloading of content via Internet, VOD and DVD retail (assuming purchases were made online and delivered by mail or courier). This set of business models offers the consumer a greater choice set (movie back catalog), besides greater flexibility and convenience compared to brick and mortar retail, PPV, broadcast TV and specialized movie channels (quadrant II). Quadrant III presents business models that, despite not meeting the need for domestic consumption of movies, gather resources that make it possible to do so.

The OFT reports that there is sufficient evidence suggesting that the company Lovefilm considers all types of video content delivery channels as its competitors. In line with the discussion in the preceding section (see Fig. 1), it means that other forms of content delivery may be able to impose ex-post competitive pressure on the merged companies, thus challenging its economic rent. It is interesting to note that from a resource-based perspective (Fig. 2), one may identify three implicit assumptions underlying the OFT conclusion. First, the OFT conclusion is based on the idea that the download via the internet, the DVD retail and the VOD impose fierce competition on online DVD rental. They can do so because they have similar resources that enable them to fulfill the same consumer need. Second, because companies in quadrant II have weak capabilities in offering flexibility to consumers, the OFT conclusion depends on the assumption of high cross elasticity of demand between the products and services offered by companies located in quadrant I and those located in quadrant II. Finally, the OFT conclusion is founded on the assumption of low entry barriers so that companies located in quadrant III can impose competitive pressure on the companies located in quadrant I.

Largely, the goal here is not to determine whether the analysis undertaken by the OFT was appropriate or not. The objective is to show how the analysis of companies' resources can generate insights on antitrust analysis which cannot be generated from received approaches.

\section{What comes next?}

Although I have illustrated the application of the RBV logic to antitrust, much of the previous discussion is based on a static idea of manufacturing industries. While this fact is a clear limitation of my paper, it also invites us to push the boundaries of the discussion in new directions. In what follows, I outline two potential directions for future research.

A first direction comes from the emergence of business ecosystems as a new organizational form. A business ecosystem

\footnotetext{
14 Peteraf and Barney (2003: 316) note that "[w]hile factors, in general, may range from pedestrian and poor quality factors, to those that are rare and special

[...] we focus on those factors that have a significant positive effect on either the economic costs or perceived benefits associated with an enterprise's products (Peteraf, 2001). Wernerfelt (1989) refers to these resources as critical resources, a term which includes both resources and capabilities".
} 
is a network of organizations, which make possible the provision of a given product or service through both competition and cooperation. According to Moore (1998, p. 168), a business ecosystem is an "extended system of mutually supportive organizations; communities of customers, suppliers, lead producers, and other stakeholders, financing, trade associations, standard bodies, labor unions, governmental and quasigovernmental institutions, and other interested parties. These communities come together in a partially intentional, highly self-organizing, and even somewhat accidental manner".

The key aspect is that the "traditional economic theory does not focus on business ecosystems as a distinct form of organization and does not provide conceptual templates that can be used to detect, inspect, and assess business ecosystem" (Moore, 2006, p. 35). However, in its heart, business ecosystems are based on core resources and capabilities, which are exploited with the purpose of producing a core product or service (Moore, 1996). It means that the RBV may bring important contributions to the discussion, focusing on organizational and technological trade-offs. Kappor and Lee (2013), for instance, show how organizational forms shape new technology investments in business ecosystems. Adner and Kaapor (2010) examine how the structure of technological interdependence affects firm performance in business ecosystems.

A second direction in the application of the RBV logic to antitrust is the analysis of the relationship between competition and innovation (e.g., Shapiro, 2012). Productivity growth fostered by innovation is but one example of this, and market structures should be assessed by their ability to both deliver consumer surplus and long-run incentives to innovate. The notion of static efficiency that underlies much of my discussion could benefit from the more dynamic analysis of antitrust and strategy as developed by Teece and coauthors (e.g., Jorde \& Teece, 1990; Sidak \& Teece, 2009).

Another related area of investigation is the competition pattern associated to multi-sided platforms (e.g., Evans, 2003) mainly in the internet (e.g., Eisenmann, Parker \& Van Alstyne, 2006; Varian, 1999). Although recent studies have discussed the contractual nature of platforms (e.g., Monteiro, Farina \& Nunes, 2014), it is still necessary to deepen the investigation of the underlying resources that support this specific organizational form. Potential relevant antitrust insights may derive from such investigation.

\section{Conclusion}

The present article is divided into two parts. Initially, I undertake a review of the current debate between antitrust and strategy. It is specifically noted that much of the contemporary discussion on the subject is focused on the productivity-based approach proposed by Porter (2001). This approach, while shedding light on important antitrust issues, is to some degree not fully innovative, since both Porter and the traditional economic antitrust analysis seek inspiration in the same source (Industrial Organization). In the second part of the paper, I propose a new approach to antitrust based on the resource-based view of strategy. This approach is particularly useful in examining the conditions of market rivalry, being a complement - not necessarily a substitute - to the traditional antitrust economic analysis. The application of the RBV to antitrust is appealing because it encourages a more microanalytical view of the phenomenon of competition, favoring a more detailed study of the idiosyncrasies of firms.

As a research agenda, future studies should seek new areas within antitrust in which the RBV can contribute. Researchers should pay particular attention to RBV potential contributions for the antitrust assessment of business ecosystems, the dynamic conditions of competition, and multi-sided platforms. Similarly, it is expected that antitrust agencies be opened for these new approaches. It is increasingly imperative that those responsible for the enforcement of the antitrust laws be more connected with those who are affected by their decisions, i.e., entrepreneurs and managers. The antitrust approach inspired by the resource-based view of strategy is well suited to accomplish this task.

\section{Conflicts of interest}

The author declares no conflicts of interest.

\section{References}

Adner, R., \& Kaapor, R. (2010). Value creation in innovation ecosystems: How the structure of technological interdependence affects firm performance in new technology generations. Strategic Management Journal, 31, 306-333.

Baker, J. B., \& Salop, S. C. (2001). Should concentration be dropped from the merger guidelines? University of West Los Angeles Law Review, 33, 3-16.

Barney, J. B. (1991). Firm Resources and Sustained Competitive Advantage. Journal of Management., 17(1), 99-120.

Barney, J. B. (1997). Gaining and sustaining competitive advantage. Upper Saddle River, NJ: Pearson Prentice Hall.

Baumol, W. J., Panzar, J. C., \& Willig, R. D. (1982). Contestable markets and the theory of industry structure. San Diego: Harcourt Brace Jovanovich.

Carlton, D. W., \& Keating, B. (2015). Antitrust transaction costs, and merger simulation with nonlinear pricing. The Journal of Law \& Economics, 58(2), 269-289.

Caves, R. E., \& Porter, M. (1977). From entry barriers to mobility barriers: Conjectural decisions and contrived deterrence to new competition. Quarterly Journal of Economics, 91, 241-262.

Coate, M. C., \& Ulrick, S. W. (2016). Unilateral effects analysis in differentiated product markets: Guidelines policy, and change. Review of Industrial Organization, 48(1), 45-68.

Davidson, K. M. (2012). Porter and Weller: An antitrust odd couple? Commentary,. Available at: http://www.antitrustinstitute.org/files/467.pdf (accessed 12.12.12)

Demsetz, H. (1973). Industry structure, market rivalry, and public policy. Journal of Law and Economics, 16(1), 1-9.

Einhorn, M. (2001). Five forces in search of a theory: Michael Porter on Mergers. University of West Los Angeles Law Review, 33, 35-43.

Eisenmann, T., Parker, G., \& Van Alstyne, M. (2006). Strategies for two-sided markets. Harvard Business Review, 84(10), 92-101.

Evans, D. S. (2003). The antitrust economics of multi-sided platform markets. Yale Journal on Regulation, 20, 325-382.

Foer, A. A. (2002). The third leg of the antitrust stool. Journal of Public Policy \& Marketing, 21(2), 227-231.

Foer, A. A. (2003). The third leg of the antitrust stool: What the business schools have to offer to antitrust. New York Law School Law Review, 47(21), 21-49.

Foss, N. J. (2005). Strategy, economic organization and the knowledge economy: The coordination of firms and resources. New York: Oxford University Press.

Harris, B. C., \& Simons, J. J. (1991). Focusing market definition: How much substitution is necessary? The Journal of Reprints for Antitrust Law and Economics, 21, 151 
Hawker, N. W. (2003). Antitrust insights from strategic management. New York Law School Law Review, 47(21), 67-85.

Jorde, T. M., \& Teece, D. J. (1990). Innovation and cooperation: Implications for competition and antitrust. The Journal of Economic Perspectives, 4(3), 75-96.

Kaapor, R., \& Lee, J. M. (2013). Coordinating and competing in ecosystems: How organizational forms shape new technology investments. Strategic Management Journal, 34, 274-296.

Katz, M. L., \& Shapiro, C. (2003). . pp. 49-56. Critical loss: Let's tell the whole story (Spring 2003) Antitrust Magazine.

Leary, T. B. (2003). The dialogue between students of business and students of antitrust. New York Law School Law Review, 47(21).

Locketta, A., \& Thompson, S. (2001). The resource-based view and economics. Journal of Management, 27, 723-754.

Monteiro, G. F. A., Farina, E. M. M. Q., \& Nunes, R. (2014). The contractual nature of two-sided platforms: A research note. Economic Analysis of Law Review, 5(1), 153-165.

Moore, J. F. (1996). The death of competition: Leadership \& strategy in the age of business ecosystems. New York: Harper Business.

Moore, J. F. (1998). The rise of a new corporate form. Washington Quarterly, 21(1), 167-181

Moore, J. F. (2006). Business ecosystems and the view of the firm. The Antitrust Bulletin, 51(1), 31-75.

Nevo, A. (2000). Mergers with differentiated products: The case of the readyto-eat cereal industry. The RAND Journal of Economics, 31(3), 395-421.

Oberholzer-Gee, F., \& Yao, D. A. (2010). Antitrust - What role for strategic management expertise? Boston University Law Review, 90, 1457-1477.

Peteraf, M. A. (1993). The cornerstones of competitive advantage: A resourcebased view. Strategic Management Journal., 14(3), 179-191.

Peteraf, M. A., \& Barney, J. B. (2003). Unraveling the resource-based tangle. Managerial and Decision Economics, 24, 309-323.

Peteraf, M. A., \& Bergen, M. E. (2003). Scanning dynamic competitive landscapes: A market-based and resource-based framework. Strategic Management Journal, 24, 1027-1041.

Pleatsikas, C., \& Teece, D. (2001). The analysis of market definition and market power in the context of rapid innovation. International Journal of Industrial Organization, 19, 665-693.
Porter, M. E. (1985). Competitive advantage: Creating and sustaining superior performance. New York: The Free Press.

Porter, M. E. (1990). The competitive advantage of nations. New York: Free Press.

Porter, M. E. (2001). Competition and antitrust: Towards a productivity-based approach to evaluating mergers and joint ventures. University of West Los Angeles Law Review, 33, 17-34.

Rumelt, R. P. (1984). Towards a strategic theory of the firm. In B. Lamb (Ed.), Competitive strategic management. Englewood Cliffs, NJ: Prentice Hall.

Scherer, F. M., \& Ross, D. (1990). Industrial market structure and economic performance. USA: Houghton Mifflin Company.

Shapiro, C. (2012). The rate direction of economic activity revisited. In J. Lerner, \& S. Stern (Eds.), Competition and innovation: Did arrow hit the bull's eye? (pp. 361-410). Chicago: The University of Chicago Press Books.

Sidak, J. G., \& Teece, D. J. (2009). Dynamic competition in antitrust law. Journal of Competition Law \& Economics, 5(4), 581-631.

Teece, D. J. (1986). Profiting from technological innovation: Implications for integration, collaboration licensing and public policy. Research Policy, 15, 285-305.

Varian, H. (1999). Market structure in the network age. prepared for understanding the digital economy conference, May 25-26 1999. Washington, DC: Department of Commerce.

Weller, C. (2001a). An evolution of Merger-JV analysis: The productivity paradigm as a positive antitrust policy for competitiveness and prosperity. University of West Los Angeles Law Review, 33, 45-55.

Weller, C. (2001b). Harmonizing antitrust worldwide by evolving to Michael Porter's dynamic productivity growth analysis. The Antitrust Bulletin, XLVI(4), 879-917.

Werden, G. J. (2001). Merger policy for the 21st century: Charles D Weller's guidelines are not up to the task. University of West Los Angeles Law Review, 33, 57-70.

Wernerfelt, B. (1984). A resource-based view of the firm. Strategic Management Journal, 5, 171-180.

Wernerfelt, B. (1989). From critical resources to corporate strategy. Journal of General Management, 14, 4-12.

Williamson, O. E. (1975). Markets and hierarchies. New York: The Free Press. 